\title{
Comparing Local and Commercial Breeds on Functional Traits and Profitability: The Case of Reggiana Dairy Cattle
}

\author{
G. Gandini, ${ }^{\star 1}$ C. Maltecca, ${ }^{\star} \dagger$ F. Pizzi, $\ddagger$ A. Bagnato,${ }^{*}$ and R. Rizzi ${ }^{\star}$ \\ ${ }^{*}$ Department of Veterinary Science and Technology for Food Safety, University of Milan, Via Celoria 10, 20133 Milan, Italy \\ †Department of Dairy Science, University of Wisconsin, Madison 53706 \\ †Institute of Biology and Agricultural Biotechnology, National Research Council, Via Bassini 15, 20133 Milan, Italy
}

\section{ABSTRACT}

The objective of this study was to compare fertility, longevity, milkability, and profitability of cows from the Reggiana and Holstein breeds in northern Italy. Profitability was gauged for each breed, with consideration of economic incentive programs and alternative milk pricing scenarios. Calving to first service interval, days open, and calving interval were significantly shorter in Reggiana than in Holstein cows. Reggiana cows conceived approximately one estrus cycle before Holstein and had a calving interval $33 \mathrm{~d}$ shorter. Holstein cows released a significantly higher quantity of milk per unit of time (1.81 vs. $1.28 \mathrm{~kg} / \mathrm{min})$. Reggiana cows had longer expected total and productive lives than Holstein cows, by 5.8 and 10.0 mo, respectively. Replacement rate was $26 \%$ higher in the Holstein. Standard 305-d milk production was 5,360 and 7,870 kg in Reggiana and Holstein, respectively. Comparing breeds on annual milk and meat production, instead of standard 305-d milk yield, changed marginally the difference in annual profitability between the Reggiana and Holstein, from -€696 to -€679 per cow per year. Including feeding, milking, replacement, and insemination costs reduced the gap between breeds by $32 \%$, from -€679, measured on annual milk and meat production, to $-€ 460$. These differences in profitability assumed a pricing scenario referring to milk sold to the dairy industry where protein and fat contents are valued but not the breed origin of milk. Incentive payments to farmers of endangered cattle compensated partially (22\%) the lower income from Reggiana cows. When Reggiana milk production was sold as branded Parmigiano Reggiano cheese, Reggiana cows were more profitable than Holstein cows by $€ 1,953$ per cow per year.

Key words: functional trait, profitability, breed comparison, Reggiana cattle

Received April 6, 2006.

Accepted November 28, 2006.

${ }^{1}$ Corresponding author: gustavo.gandini@unimi.it

\section{INTRODUCTION}

The development of dairy cattle breeds with potential for high milk production in intensive production systems has threatened internationally the existence of many local breeds of dairy cattle, which have been associated with lower input/output systems (Sherf, 2000). Maintaining a variety of local breeds, along with a variety of associated farming systems, is recommended by the Convention of Biological Diversity (1992) as the optimum strategy for the conservation of genetic variation for use in the future for development of animal production. The dynamics of loss of local breeds are poorly understood. In most cases, local breeds have probably declined in number of animals because of low potential for profit compared with other breeds in intensive production systems. Economic compensation to dairy producers who maintain herds of local breeds of cattle has been provided by some local government entities and by European Union agricultural policy since 1992. Economic incentives to maintain herds of local breeds of dairy cattle can be effective in halting the loss of local breeds; however, this compensation cannot be expected to continue forever, and in many situations, dairy producers who maintain herds of cows with local breeds might continue to struggle with profitability (Signorello and Pappalardo, 2003).

Local breeds of dairy cattle should have maintained hardiness and natural adaptation for low-input production systems; therefore, these breeds could have advantages for functional traits, such as fertility, disease resistance, and longevity, which have a large impact on profitability of dairying. Advantages for functional traits could result in lower input costs for animal management and replacement costs (Groen et al., 1997), and an assessment of local breeds for the functional traits is necessary to develop genetic improvement programs that are sustainable (Olesen et al., 2000).

For most local breeds of dairy cattle, reliable estimates of performance do not exist. Appropriate performance recording systems for local breeds might identify traits for which the breeds potentially could have 
strengths and, thereby, provide justification for breed conservation and promotion. Milk from local breeds can be used to develop branded dairy products to exploit the uniqueness of breeds. Numerous examples exist of branded products from local breeds that have been successfully promoted and marketed (Morand-Fehr et al., 1998); however, these successes are barely mentioned in the scientific literature.

The Reggiana breed of dairy cattle was developed in the Emilia Romagna region of northern Italy, which is the same region where Holstein cows are now milked to produce most Parmigiano Reggiano cheese. In the 1940 s, the population of Reggiana cows was greater than 40,000; however, that number progressively regressed to fewer than 500 cows in the early 1980s as Reggiana cows were displaced by Holstein cows with higher milk production. Since the 1990s, the Reggiana breed has gradually increased in cow numbers, but the desirable attributes of the breed are mostly not documented.

Today, most Reggiana cows are kept in mixed herds that also have Holstein cows. In 2000, about 850 milkrecorded Reggiana cows were distributed in 86 mixedbreed herds (74\% of Reggiana cows) and in 9 Reggianaonly herds (26\% of cows). Mean milk production of Reggiana cows is $32 \%$ lower than Holstein cows, which is a large difference. This difference in milk production explains the movement away from Reggiana cows and toward Holstein cows. Milk from Reggiana cows has higher milk solids than milk from Holsteins; and milk from Reggiana cows is particularly well-suited for cheese production because of its high percentage of $\mathrm{CN}$ and superb properties for rennet coagulation (Mariani and Pecorari, 1987). Since 1992, consortia of dairy producers have initiated the production of a branded Parmigiano Reggiano cheese, which is made exclusively from milk from Reggiana cows. The branded cheese is sold at premium prices compared with standard Parmigiano Reggiano cheese and is revitalizing interest in Reggiana cows.

The objective of this study was to compare the functional traits fertility, longevity, milkability, and profitability of cows from the Reggiana and Holstein breeds in northern Italy. Fertility (e.g., Boichard, 1990) in dairy cattle is one of the most important traits after milk production. Longevity is a complex trait that combines several traits including disease resistance (e.g., Dekkers and Jairath, 1994), and it was used here because records on disease were not available. Farmers often complain about the poor milkability of Reggiana cows, however. Profitability was gauged for each breed, with consideration of economic incentive programs and alternative milk pricing scenarios.

\section{MATERIALS AND METHODS}

\section{Functional Traits}

Information Sources and Data Structure. The 2 breeds in this study were compared based on 1) data from the mixed, milk recorded, Reggiana-Italian Holstein herds present in the major Reggiana breed farming area, namely, Reggio Emilia and Parma provinces; 2) data from the 2 largest mixed Reggiana-Italian Holstein herds, collected over a period of 24 mo, from January 2000 to December 2001. One or both data sources were used in analyzing fertility, longevity, and milkability, depending upon data availability. The average size of the 2 experimental herds during the data collection period was 165 cows (63\% Holstein, 37\% Reggiana) for herd 1 and 110 cows (18\% Holstein, 82\% Reggiana) for herd 2, with an average of 37 and $26 \%$ first-parity animals among Holstein and Reggiana cows, respectively. Management conditions for the 2 breeds, along with milking structures and routines, were equal within herd and comparable across herds.

Fertility. The following parameters were estimated: calving interval (CI), number of services per pregnancy (NS), days from calving to first service (CFS), days open (DO), conception rate (CR) measured as the inverse of NS, and the proportion of pregnant cows by service order. Calving interval analysis was performed on a data set of milk-recorded Reggiana and Holstein cows coming from 69 mixed-breed herds. Data included lactations ranging from January 1997 to December 2002. Calving intervals $<300$ and $>720 \mathrm{~d}$ were excluded from the analysis. Average calving interval was estimated on 669 records coming from 422 Reggiana cows and on 2,247 records coming from 1,752 Holstein cows. Because insemination date information was not available in the milk recorded populations, NS, CFS, DO, and CR were estimated on a total of 432 observations from 118 Reggiana and 109 Italian Holstein cows collected in the 2 mixed herds over the 24-mo experimental period. On the same data set heat detection rate was estimated with the formula $\{21 /[(\mathrm{DO}-\mathrm{CFS}) /(\mathrm{NS}-1)]\}$, which allows use of only conceptions with 2 or more inseminations and ignores missed heats prior to the first insemination. Table 1 summarizes the information used for the analysis of the different traits.

Milkability. Total milking time was recorded in the 2 experimental mixed herds using a timer. Both herds had a 12-stall milking parlor with glass jars to measure milk production. Total milking time (MT), defined as the time from seating of the teat cups until their removal, was used to measure milking speed. In addition, milk flow (MF) was calculated as the ratio between milk yield and MT, both recorded at the afternoon milking. A total of 771 milking records coming from 108 
Table 1. Information for the analysis of fertility, milkability, and longevity traits in Reggiana and Holstein breeds

\begin{tabular}{|c|c|c|c|c|c|}
\hline \multirow[b]{2}{*}{ Trait } & \multirow[b]{2}{*}{ Data source } & \multicolumn{2}{|c|}{ Reggiana } & \multicolumn{2}{|c|}{ Holstein } \\
\hline & & $\underset{\mathrm{n}}{\text { Records, }}$ & $\begin{array}{c}\text { Cows, } \\
\mathrm{n}\end{array}$ & $\begin{array}{c}\text { Records, } \\
\mathrm{n}\end{array}$ & $\begin{array}{c}\text { Cows, } \\
\mathrm{n}\end{array}$ \\
\hline Services per pregnancy (NS) & Experimental herd 1 & 125 & 60 & 55 & 31 \\
\hline $\begin{array}{l}\text { Calving to first service interval (CFS) } \\
\text { Days open (DO) }\end{array}$ & Experimental herd 2 & 127 & 58 & 125 & 78 \\
\hline Milking time (MT) & Experimental herd 1 & 321 & 82 & 173 & 50 \\
\hline Milk flow (MF) & Experimental herd 2 & 87 & 26 & 190 & 52 \\
\hline Calving interval (CI) & Milk recorded population & 669 & 422 & 2,247 & 1,752 \\
\hline $\begin{array}{l}\text { Age at first calving (AFC) } \\
\text { Herd life (HL) } \\
\text { Productive life (PL) }\end{array}$ & Milk recorded population & 881 & 881 & 4,684 & 4,684 \\
\hline
\end{tabular}

Reggiana and 102 Holstein cows were available for the analysis (Table 1).

Longevity. A data set including milk-recorded Reggiana and Holstein cows born after 1979, coming from 90 mixed-breed herds, was analyzed. Cows with age at first calving less than 18 or greater than 42 mo and cows with no first calving date were excluded from the analysis. Disposal date was attributed to cows with no culling date according to Foster et al. (1989). After editing, 881 and 4,684 records for Reggiana and Holstein, respectively, were available for statistical analysis (Table 1). The traits analyzed were herd life (HL), defined as time between birth and last test day; productive life (PL), defined as time between first calving and last test day; and age at first calving. Replacement rate was also computed as the inverse of expected PL.

Statistical Analysis. Analysis of variance was used to investigate the effect of breed on NS, CFS, DO, CI, MT, MF, and age at first calving. Number of services, CFS, DO, MT, MF, and CI were analyzed with the MIXED procedure of SAS (2001). The random effect of cow within breed $\times$ herd interaction was fitted for all the traits. For NS, CFS, and DO, breed, herd, breed $\times$ herd interaction, season, and parity were included in the model as fixed effects. For MT and MF, DIM and milking month $\times$ breed interaction were included, along with the aforementioned fixed effects. In the CI analysis, fixed effects of breed, herd $\times$ calving year $\times$ season interaction, and parity were considered. Age at first calving was analyzed with a fixed model including the effects of breed and herd $\times$ year of birth interaction, with the GLM procedure of SAS (2001). Lactations beyond the fifth were grouped into one level. Seasons were defined as December-February, March-May, June-August, and September-November. Student's $t$-test was used to determine the significance of differences between breeds. Proportion of pregnant cows by service order was analyzed using logistic regression with 1 and
0 indicating conceiving or not conceiving cows, respectively. Herd life and PL were analyzed with a Cox regression model of the following form:

$$
\lambda(\mathrm{t})=\lambda_{0}(\mathrm{t}) \exp (\mathrm{B}+\mathrm{HY}+\mathrm{A}),
$$

where $\lambda(t)=$ the hazard function, which represents the risk of a cow being culled after $t$ days of $\mathrm{HL}$ or PL; $\lambda_{0}(\mathrm{t})=$ the baseline hazard function, an arbitrary function that describes the natural ageing process; $\mathrm{B}=$ the fixed timeindependent effect of breed; $\mathrm{HY}=$ the fixed time-independent effect of herd $\times$ year of birth interaction; and $\mathrm{A}=$ the fixed time-independent effect of age at first calving. Expected values for HL and PL were obtained as reported by Kalbfleisch and Prentice (1980) by using the Survival Kit program (Ducrocq and Sölkner, 1998).

\section{Profit Equation}

Profitability difference between the 2 breeds was calculated as follows:

$$
\mathbf{D P}=\left(\mathbf{R}_{\mathbf{R}}-\mathbf{C}_{\mathbf{R}}\right)-\left(\mathbf{R}_{\mathbf{H}}-\mathbf{C}_{\mathbf{H}}\right),
$$

where DP is the difference in profitability, $\mathbf{R}_{\mathbf{R}}$ and $\mathbf{R}_{\mathbf{H}}$ are average revenues, and $\mathbf{C}_{\mathbf{R}}$ and $\mathbf{C}_{\mathbf{H}}$ are average costs, respectively, in Reggiana and Holstein breeds, measured as $€$ per cow per year (on January 2001, €1= US \$0.94).

Two milk selling scenarios were analyzed in terms of DP. The first refers to milk sold directly to the dairy industry (S-Milk) and priced on fat and protein contents. The second scenario relates to farmer's cooperatives where Holstein and Reggiana milks are processed separately to produce, respectively, a generic Parmigiano Reggiano cheese and a branded Reggiana Parmigiano Reggiano cheese. In this second scenario, revenues come from the cheese sold (S-Cheese). For the 
first scenario, average milk price paid by the dairy industry observed in the farming area in the period 2000 2003 was used in the analysis. For the second scenario, data were collected over the same period in the largest dairy cooperative, covering $65 \%$ of the production. Information on number of cooperatives and herds producing Reggiana Parmigiano Reggiano cheese and amount of cheese produced were collected over the period 19942003. Within the S-Milk pricing system, the effect on $\mathrm{DP}$ of current incentive payments to endangered cattle farming following European Union regulation (S-Milk + Ip), was analyzed.

For each breed, average revenues and costs in equation [1] were assumed to be linear functions as

$$
\begin{aligned}
& \mathbf{R}=\mathbf{R}_{\mathrm{pr}} \mathbf{M P}+\mathbf{R}_{\mathrm{cl}} \mathbf{N C L}+\mathbf{R}_{\mathrm{cw}} \mathbf{C W} / \mathbf{P L}+\mathbf{R}_{\mathrm{ip}}, \\
& \text { and } \\
& \mathbf{C}=\mathbf{C}_{\mathbf{r}}(1 / \mathbf{P L})+\mathbf{C}_{\mathbf{m}} \mathbf{H M}+\mathbf{C}_{\mathbf{f}} \mathbf{M P}+\mathbf{C}_{\mathbf{i}} \mathbf{N S Y}
\end{aligned}
$$

where $\mathbf{R}_{\mathbf{p r}}=$ value of milk production ( $\left.€ / \mathrm{kg}\right)$, alternatively: 1 ) value of milk sold, in the S-Milk pricing system, is based on standard $3.70 \%$ fat and $3.25 \%$ protein contents. Higher and lower contents are priced with $\pm € 0.03$ and $€ 0.06$ for additional $1 \%$ of milk protein and fat; 2) value of cheese sold at 24 mo of ripening, for the S-Cheese pricing system; MP = milk production $(\mathrm{kg})$, alternatively: 1 ) official standard 305-d milk yield in the Parma and Reggio provinces; 2) yearly milk production, considering breed calving interval; 3) yearly cheese yield, considering breed \% cheese yield (Castagnetti et al., 1986); $\mathbf{R}_{\mathrm{cl}}=$ value of calf at $1 \mathrm{wk}$ of age (€/calf); $\mathbf{N C L}=$ number of calves 1 -wk-old sold per cow per year, according to breed calving interval and replacement rates; $\mathbf{R}_{\mathbf{c w}}=$ value of carcass of culled cow $(€ / \mathrm{kg}) ; \mathbf{C W}=$ weight of carcass of culled cow $(\mathrm{kg}) ; \mathbf{P L}=$ expected productive life, as previously defined (year); $\mathbf{R}_{\mathbf{i p}}=$ incentive payment ( $€ /$ cow per year) for Reggiana herds, following European Union regulation; $\mathbf{C}_{\mathbf{r}}=$ rearing costs per heifer (€/heifer); $\mathbf{C}_{\mathbf{m}}=$ milking costs $(€ / \mathrm{h}) ; \mathbf{H M}=$ milking hours per cow per year, assuming a 12-stall milking parlor, considering breed MT; $\mathbf{C}_{\mathbf{f}}=$ feed costs for milk production ( $€ / \mathrm{kg}$ of milk), considering requirements for Parmigiano Reggiano production (e.g., silage not allowed), specific breed rations, and local feedstuffs costs; $\mathbf{C}_{\mathbf{i}}=$ insemination cost ( $€ /$ insemination) including semen and technician costs; $\mathbf{N S Y}=$ number of inseminations per year, considering calving interval and number of services per pregnancy.

Production parameters, revenues, and costs used to derive $\mathrm{R}$ and $\mathrm{C}$ are reported in Tables 2 and 3, respectively. Carcass weight of culled cows was set to $300 \mathrm{~kg}$ for both breeds. Because of limited amount of data, it
Table 2. Parameters used to estimate difference in profitability between breeds

\begin{tabular}{lcc}
\hline & \multicolumn{2}{c}{ Breed } \\
\cline { 2 - 3 } Parameter & Reggiana & Holstein \\
\hline 305-d milk yield, ${ }^{1} \mathrm{~kg}$ & 5,360 & 7,870 \\
Year milk yield, $^{2} \mathrm{~kg}$ & 5,240 & 7,690 \\
Milk protein, ${ }^{1} \%$ & 3.38 & 3.21 \\
Milk fat, $^{1} \%$ & 3.51 & 3.53 \\
Year protein yield, ${ }^{1} \mathrm{~kg}$ & 177 & 247 \\
Year fat yield, ${ }^{1} \mathrm{~kg}$ & 184 & 271 \\
Cheese yield, $^{3} \%$ & 7.53 & 7.03 \\
Calves 1-wk-old sold per cow per year, ${ }^{4} \mathrm{n}$ & 0.81 & 0.72 \\
Milking hours per cow per year, ${ }^{5} \mathrm{~h}$ & 84.3 & 79.6 \\
Inseminations per cow per year, $^{6} \mathrm{n}$ & 1.42 & 1.50 \\
\hline
\end{tabular}

${ }^{1}$ Official standard 305-d milk yield in the Parma and Reggio Emilia provinces.

${ }^{2}$ Official standard 305-d milk yield in the Parma and Reggio Emilia provinces, corrected for calving interval (Table 4).

${ }^{3}$ From Castagnetti et al. (1986).

${ }^{4}$ According to calving interval and replacement rate (Tables 4 and $5)$.

${ }^{5}$ According to milking time (Table 4).

${ }^{6}$ According to calving interval and services per pregnancy (Table $4)$.

was not possible to estimate veterinary costs. Revenues, such as value of extra replacement heifers, and costs not included in equations [2] and [3] were assumed to be equal in the 2 breeds.

\section{RESULTS AND DISCUSSION}

\section{Functional Traits}

Fertility. Least square means for NS, DO, CI, and CFS are given in Table 4. Number of services per pregnancy did not differ significantly between breeds. Days open, CI, and CFS were significantly shorter in Reggi-

Table 3. Revenues and costs $(€)$ used to estimate differences in profitability between breeds

\begin{tabular}{lcc}
\hline & \multicolumn{2}{c}{ Breed } \\
\cline { 2 - 3 } Parameter & Reggiana & Holstein \\
\hline Value of milk, S-Milk pricing system, ${ }^{1}$ per kg & 0.34 & 0.32 \\
Value of cheese, S-Cheese pricing system, & & \\
per kg & 14.15 & 7.12 \\
Value of calf at 1 wk of age $^{3}$ & 100 & 100 \\
Value of carcass of culled cow, $^{3}$ per kg & 1.65 & 1.40 \\
Incentives payment per cow $/ \mathrm{yr}^{4}$ & 100 & 0 \\
Rearing costs per heifer $^{3}$ & 1,430 & 1,500 \\
Milking costs per hour $^{3}$ & 13 & 13 \\
Feed costs per kg of milk $^{3}$ & 0.20 & 0.14 \\
Insemination costs (semen and technician) $^{3}$ & 30 & 30 \\
\hline
\end{tabular}

${ }^{1}$ Source: official bulletins 2000-2003.

${ }^{2}$ Source: the largest cooperative 2000-2003.

${ }^{3}$ Source: breed experts.

${ }^{4}$ European Community Regulation 2078/1992. 
Table 4. Least squares means \pm SE of fertility, milkability, and longevity traits, by breed

\begin{tabular}{lrr}
\hline & \multicolumn{2}{c}{ Breed } \\
\cline { 2 - 3 } Trait & \multicolumn{1}{c}{ Reggiana } & \multicolumn{1}{c}{ Holstein } \\
\hline Services per pregnancy, $\mathrm{n}$ & $1.52 \pm 0.06$ & $1.70 \pm 0.07$ \\
Calving to first service interval, d & $85.70 \pm 2.60^{\mathrm{a}}$ & $96.37 \pm 3.20^{\mathrm{b}}$ \\
Days open, d & $103.66 \pm 3.31^{\mathrm{a}}$ & $122.52 \pm 3.90^{\mathrm{b}}$ \\
Calving interval, d & $381.13 \pm 3.25^{\mathrm{a}}$ & $414.43 \pm 2.27^{\mathrm{b}}$ \\
Milking time, min & $8.22 \pm 0.20$ & $7.65 \pm 0.17$ \\
Milk flow, kg/min & $1.28 \pm 0.04^{\mathrm{a}}$ & $1.81 \pm 0.06^{\mathrm{b}}$ \\
Age at first calving, mo & $27.64 \pm 0.07$ & $27.81 \pm 0.12$ \\
\hline
\end{tabular}

${ }^{\mathrm{a}, \mathrm{b}}$ Means within rows with different superscripts differ $(P<0.01)$.

ana than in Holstein cows. Reggiana cows conceived approximately one estrus cycle (19 d) before Holstein and showed a 33-d shorter calving interval. The shorter CFS in the Reggiana could be related to the fact, often reported by farmers, that Reggiana cows show more evident signs of estrus, in particular at first heat after calving. Westwood et al. (2002) reported how Holstein cows of high genetic merit are less likely to show signs of estrus at first ovulation. Heat detection rate and average conception rate were higher in Reggiana than in Holstein cows, respectively, 61 vs. $56 \%$ and 66 vs. $59 \%$. In particular, Reggiana cows were 1.55 times $(P$ $<0.03$ ) more likely to conceive at first service compared with Holstein cows (Figure 1). Genetic antagonism between milk production and fertility is known (Butler et al., 1981; van Arendonk et al., 1989; De Vries et al., 1999; Pryce et al., 2004); the observed difference in fertility between breeds could be related to their different selection history. High-intensity selection for milk production has been used in the Holstein for many generations, but index selection was introduced in the Reggiana only recently and with low intensity to avoid high inbreeding rates.

Milkability. Breed comparison on milkability is reported in Table 4. Holstein cows released a significant

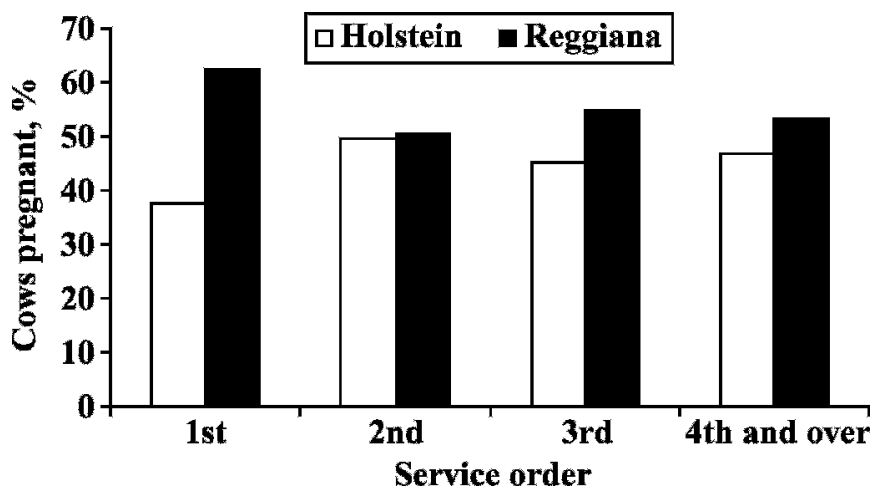

Figure 1. Proportion of cows pregnant, by service order and breed.
Table 5. Herd and productive life, hazard ratios, and replacement rate, by breed

\begin{tabular}{lcc}
\hline & \multicolumn{2}{c}{ Breed } \\
\cline { 2 - 3 } Trait & Reggiana & Holstein \\
\hline Expected herd life, mo & 70.72 & 64.91 \\
Expected productive life, mo & 47.92 & 37.90 \\
Replacement rate, \% & 25.06 & 31.74 \\
Herd life-hazard ratio & 0.71 & 1 \\
Productive life-hazard ratio & 0.69 & 1 \\
\hline
\end{tabular}

greater quantity of milk per unit of time (1.81 vs. 1.28 $\mathrm{kg} / \mathrm{min}$ ). Milking time was longer in Reggiana cows (8.22 vs. $7.65 \mathrm{~min}$ ) though not statistically significant. Literature on variation of milkability among breeds is scarce and mainly related to highly selected dairy populations. Milk flow in the Reggiana was higher than in the dual-purpose Simmental cattle and lower than in the Braunvieh (Bruckmaier et al., 1995). The poor milkability of Reggiana cows could be associated with poor udder conformation.

Longevity. Expected HL and PL, their hazard ratios, and replacement rate are presented in Table 5. Expected HL and PL were 5.81 and 10.02 mo longer in Reggiana than in Holstein cows, respectively. Hazard ratios were lower for Reggiana than for Holstein cows; Holstein cows had a 1.41 and 1.45 higher risk of being culled, respectively, from birth and from first calving. Replacement rate was $26 \%$ higher in the Holstein breed. Age at first calving did not differ between breeds (Table 4). Literature on longevity across breeds is scarce. Ghiroldi (2005) found in Italian Brown a PL of 38 mo, which is 10 mo shorter than in Reggiana. Also, a negative relationship between milk yield and survival rates attributed to differences in fertility was observed by Dillon et al. (2003) in comparing 2 Holstein-Friesian populations and the Montbeliarde and Normande cattle.

\section{Profitability}

Figure 2 illustrates the difference in profitability (DP) between Reggiana and Holstein cows for the SMilk scenario. Difference in profitability is broken down in the following 4 estimates to underline the effects of the different components: 1) on revenues from standard 305-d milk production (ST); 2) on revenues from annual milk production (R1); 3) on revenues from annual milk and meat production (R2); 4) on R2 minus replacement, milking, feeding, and insemination costs $(\mathbf{R 2}-\mathbf{C})$. The comparison of breeds based on annual milk production (R1), that with respect to ST is affected by calving interval, decreased DP only by $2 \%$, from $-€ 696$ to $-€ 679$. Adding revenues from meat production (R2), that is, 


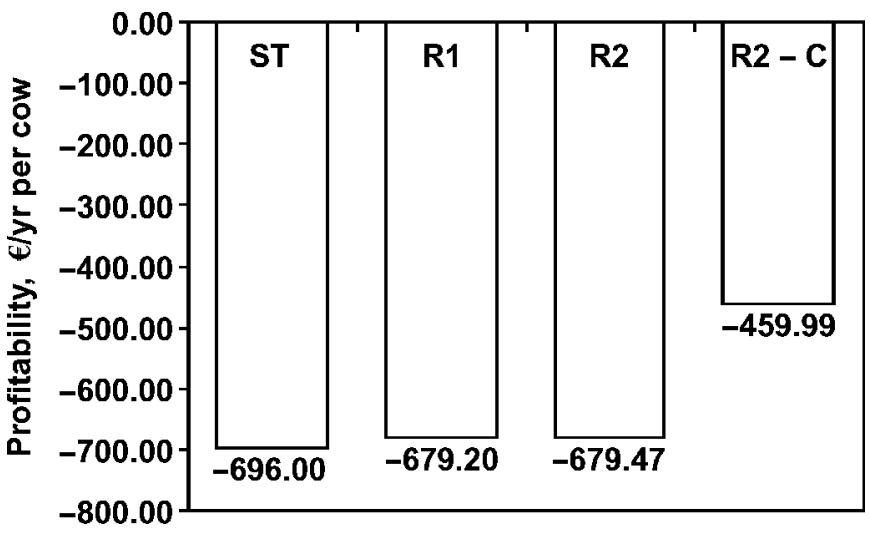

Figure 2. Difference in profitability, for the S-Milk scenario, between Reggiana and Holstein breed on revenues from standard 305$\mathrm{d}$ milk production (ST); revenues from annual milk production (R1); revenues from annual milk and meat production (R2); and R2 minus feeding, milking, replacement, and insemination costs (R2 - C).

values of carcass and calves, only slightly affected DP. In particular, Holstein has lower carcass value, but because of its shorter productive life, revenues per year were $1 \%$ higher than in Reggiana. Including costs reduced the gap between breeds by $32 \%$, passing from $-€ 679$, measured on annual milk and meat production, to $-€ 460$. In particular, considering longevity, measured as annual replacement costs, reduced DP R2 by $17 \%$. By including milking costs, DP slightly increased $(<1 \%)$ because of the longer milking time required by Reggiana cows. Feeding costs reduced the gap between breeds by $16 \%$ and insemination costs affected DP by less than $1 \%$. Estimates of differences in profitability based uniquely on standard production between local and commercial breeds varied between $-€ 260$ (horse breeds) and $-€ 1,350$ (swine breeds; Signorello and Pappalardo, 2003). Although a profitability gap between the Reggiana and Holstein breeds is evident, this study underlines that more comprehensive comparisons among local and commercial breeds are possible.

Differences in profitability reported in Figure 2 assume a pricing system that refers to milk sold to the dairy industry (S-Milk) where protein and fat contents are valued but the breed specificity of the milk is not rewarded. During the experimental period this scenario was followed by $86 \%$ of Reggiana farmers, accounting for $60 \%$ of cows. Figure 3 shows how incentive payments or, as an alternative, the development of a branded dairy product affected DP. The strategy of incentive payments (S-Milk + Ip) compensated partially (22\%) the lower income from Reggiana cows with respect to Holstein cows, by reducing DP R2-C to -€360/cow per year. When milk production was sold as generic (Holstein milk) vs. branded Reggiana (Reggiana milk) Par-

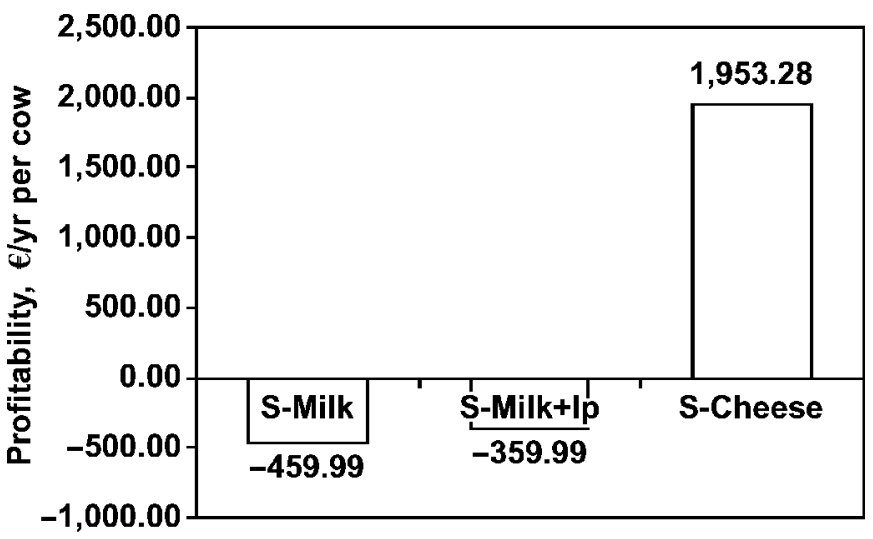

Milk pricing system/incentives

Figure 3. Difference in profitability between Reggiana and Holstein breed as a function of milk pricing scenario and presence of economic incentives: milk sold to dairy industry (S-Milk), S-Milk and economic incentives to Reggiana cows (S-Milk + Ip), milk production sold as generic (Holstein), and branded (Reggiana) Parmigiano Reggiano cheese (S-Cheese).

migiano Reggiano (S-Cheese), DP changed dramatically from $-€ 460$ to $+€ 1,953$, due to the higher price of the branded Reggiana cheese. Prices of Reggiana Parmigiano Reggiano cheese were highly stable over the 4-yr period of study (2000-2003), and the S-Cheese strategy was adopted by $14 \%$ of the farmers, accounting for $40 \%$ of the cows. No studies are available on future production and market trends. The analysis of historical data shows that, from 1994 to 2003, number of dairy cooperatives and herds producing the Reggiana branded Parmigiano Reggiano cheese, and kilograms of cheese produced per day, increased from 1 to 5 , from 3 to 15 , and from 71 to 445 , respectively (Figure 4). Following this renewed interest for the breed, the number of Reggiana cows is now progressively increasing and reached 1,250 head in 2004 with an increase since 1993 of approximately $100 \%$.

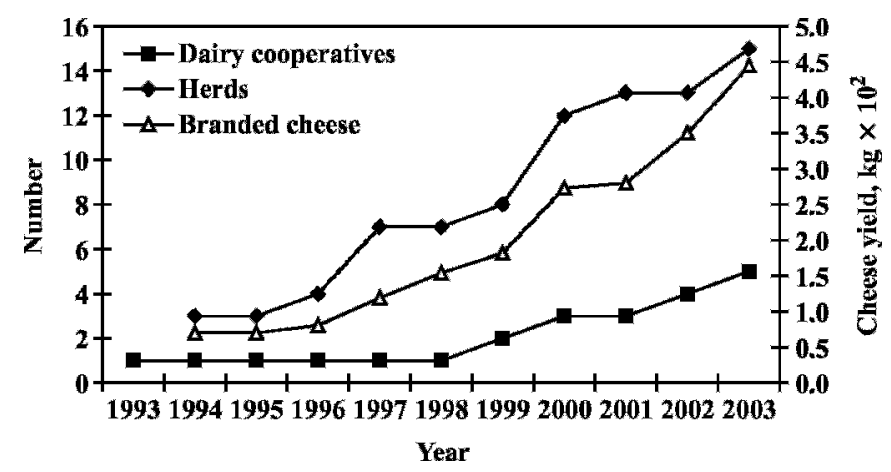

Figure 4. Evolution of number of dairy cooperatives ( $\square$ ), and herds $(\diamond)$ producing branded Reggiana Parmigiano Reggiano cheese, and branded cheese produced per day $(\triangle ; \mathrm{kg})$. 
Different factors positively influence the value of the Reggiana milk in the production of branded Parmigiano Reggiano cheese. Reggiana milk, compared with Holstein, has dairy technological properties more suitable for Parmigiano Reggiano cheese production, including better fermentative aptitude and curds with more favorable cooking and syneresis properties (Castagnetti et al., 1986, 1994). During the experimental period, cheese yield obtained at 24 mo of ripening was on average 7\% higher for Reggiana milk than for Holstein milk. A lower percentage of discarded cheese was also observed. Since its appearance on the market in 1994, the branded Reggiana Parmigiano Reggiano has been well accepted by consumers that were willing to pay from 30 to almost $100 \%$ more with respect to generic Parmigiano Reggiano cheese. The quality of Reggiana specific cheese has been awarded in several competitions, but reports on sensory analysis are, to date, not available. Marketing communication on the branded Parmigiano Reggiano cheese is centered on the traditional relationship, across centuries, between the Reggiana breed and the cheese, its health and quality properties, its uniqueness, and partially on its contribution to support the endangered breed. No investigation on perception by consumers of these values has been carried out, but a general survey that revealed how consumers appreciate Reggiana cheese mainly for its quality $(91 \%)$ and in a few cases as a fashionable product (Mora, 1997).

\section{CONCLUSIONS}

Large perceived differences in profitability between local breeds and Holsteins pose an almost insurmountable challenge for the maintenance of local breeds of dairy cattle into the future. For the Reggiana breed of northern Italy, direct government payments to dairy producers to maintain herds of Reggiana cows would likely be viewed as too costly by most Italian citizens. This study reviews 2 strategies to assist the Reggiana breed to achieve sustainability: improved methods for breed evaluation, and the development of branded products to increase the value of Reggiana milk.

Comparison of local breeds of dairy cattle and Holsteins must consider the interaction of breed characteristics and management systems. In this study, Reggiana and Holstein cows were managed together on dairy farms under similar conditions to simplify comparison of the breeds. Consideration of advantages of Reggiana cows for functional traits did little to compensate for the large difference between the Reggiana and Holstein breeds for level of milk production. Breed differences for health and disease resistance were not included in this study, however. Preliminary analysis suggests lower risks of lameness and displaced abomasums of Reggiana cows, but no differences in mastitis occurrence among breeds (G. Gandini, unpublished data). Additional studies on diseases resistance might somehow modify the differences in profitability between the 2 breeds reported here.

Breeders of Reggiana cows plan to initiate a genetic improvement program for udder conformation to improve the milkability of cows. Simulation studies have suggested that, despite a small population size, the genetic improvement of the Reggiana breed for this trait is possible (Gandini et al., 1999).

Appropriate use of unique characteristics of the Reggiana breed might provide opportunities to reduce the perception of low profitability of the breed. The development of branded products such as authentic Parmigiano Reggiana cheese should enhance the revenue derived from milking Reggiana cows. Few dairy producers in northern Italy have adopted the breed-specific branding for dairy products; however, current trends in embracing this strategy are encouraging. A persistent problem for the branded-product approach is separating the milk of Reggiana and Holstein cows in mixed-breed herds.

\section{ACKNOWLEDGMENTS}

The authors thank L. Catellani, G. Montruccoli, and R. Zanelli for the kind cooperation, A.P.A. of Reggio Emilia and ANARR for providing data, and an anonymous reviewer. Research supported by MURST contracts 9907103387_006.

\section{REFERENCES}

Boichard, D. 1990. Estimation of the economic value of conception rate in dairy cattle. Livest. Prod. Sci. 24:187-204.

Bruckmaier, R. M., E. Rothenhanger, and J. W. Blum. 1995. Milking characteristics in dairy cows of different breeds from different farms and during the course of lactation. J. Anim. Breed. Genet. 112:293-302.

Butler, W. R., R. W. Everett, and C. E. Coppock. 1981. The relationship between energy balance, milk production and ovulation in post partum Holstein cows. J. Anim. Sci. 53:742-748.

Castagnetti, G. B., A. Bagni, C. Chiavari, G. Ferri, G. Losi, and P. Mariani. 1994. Chemical composition and coagulation properties of milk from Reggiana breed dairy cows with different casein $\beta$ and $\kappa$-genotypes. Pages 151-159 in Cheese Yield and Factors Affecting its Control. Int. Dairy Fed., Brussels, Belgium.

Castagnetti, G. B., L. Grazia, G. Losi, and P. Mariani. 1986. Il latte della Reggiana nella produzione del Parmigiano Reggiano. II Prove di caseificazione. Industria del latte 22:3-22.

Convention of Biological Diversity. 1992. Online: http://www.biodiv. org/convention/convention.shtml

Dekkers, J. C. M., and L. K. Jairath. 1994. Requirements and uses of genetic evaluations for conformation and herd life. Proc. 5th World Congr. Genet. Appl. Livest. Prod., Guelph, Ontario, Canada XVII:61-68.

De Vries, M. J., S. Van Der Beek, L. M. T. E. Kaal-Lansbergen, W. Ouweltjes, and J. B. M. Wilmink. 1999. Modelling of energy 
balance in early lactation and the effect of energy deficits in early lactation on first detected estrus postpartum in dairy cows. J. Dairy Sci. 82:1927-1934.

Dillon, P., S. Snijders, F. Buckley, B. Harris, P. O'Connor, and J. F. Mee. 2003. A comparison of different dairy cow breeds on a seasonal grass-based system of milk production. 2. Reproduction and survival. Livest. Prod. Sci. 83:35-42.

Ducrocq, V., and J. Sölkner. 1998. The Survival Kit version (V3.0)_A package for large analyses of survival data. Proc. 6th World Congr. Genet. Appl. Livest. Prod., Armidale, Australia XXVII:447-448.

Foster, W. W., A. E. Freeman, P. J. Berger, and A. Kuck. 1989. Association of type traits scored linearly with production and herdlife of Holsteins. J. Dairy Sci. 72:2651-2664.

Gandini, G., A. Bagnato, and R. Rizzi. 1999. Expected genetic response from aggregate indexes in the Reggiana cattle. Pages 152 154 in Proc. XIII A.S.P.A. Congr., Piacenza, Italy.

Ghiroldi, S. 2005. La longevitá funzionale e la morfologia nella razza bruna. La razza Bruna 2 (Suppl.):5-6.

Groen, A. F., T. Steine, J. J. Colleau, J. Pedersen, J. Pribyl, and N. Reinsch. 1997. Economic values in dairy cattle breeding, with special reference to functional traits. Report of an EAAP-working group. Livest. Prod. Sci. 49:1-21.

Kalbfleisch, J. D., and R. L. Prentice. 1980. The statistical analysis of failure time data. John Wiley and Sons, New York, NY.

Mariani, P., and M. Pecorari. 1987. Fattori genetici, attitudine alla caseificazione e resa del latte in formaggio. Sci. Tecn. Latt. Cas. $38: 286-326$
Mora, C. 1997. La differenziazione nei prodotti tipici: il parmigiano reggiano delle vacche rosse. PhD Thesis. Universitá degli Studi di Parma, Italy

Morand-Fehr, P., R. Rubino, J. Boyazoglu, and J. C. Le Jaouen. 1998. Réflexions sur l'histoire, la situation actuelle et l'évolution des produits animaux typiques. Pages 17-29 in Basis of the Quality of Typical Mediterranean Animal Products. EAAP Publication No. 90. J. C. Flamant, D. Gabiña, and M. Espejo Diaz, ed. Wageningen Pers, Wageningen, the Netherlands.

Olesen, I., A. F. Groen, and B. Gjerde. 2000. Definition of animal breeding goals for sustainable production systems. J. Anim. Sci. 78:570-582.

Pryce, J. E., M. D. Royal, P. C. Garnsworthy, and I. L. Mao. 2004. Fertility in the high-producing dairy cow. Livest. Prod. Sci. $86: 125-135$.

SAS. SAS User's Guide. Statistics, Release 8.2. 2001. SAS Inst. Inc., Cary, NC.

Sherf, B. D. 2000. World watch list for domestic animal diversity. 3rd ed. FAO, Rome, Italy.

Signorello, G., and G. Pappalardo. 2003. Domestic animal biodiversity conservation: A case study of rural development plans in the European Union. Ecol. Econ. 45:487-499.

Van Arendonk, J. A. M., R. Hovenier, and W. De Boer. 1989. Phenotypic and genetic associations between fertility and production in dairy cows. Livest. Prod. Sci. 21:1-12.

Westwood, C. T., I. J. Lean, and J. K. Garvin. 2002. Factors influencing fertility of Holstein dairy cows: A multivariate description. J. Dairy Sci. 85:3225-3237. 